\title{
Decadal Changes in the Near-Surface Air Temperature in the Western Side of the Antarctic Peninsula
}

\author{
Jorge F. Carrasco ${ }^{1,2,3}$ \\ ${ }^{1}$ Dirección Meteorológica de Chile, Estación Central, Chile \\ ${ }^{2}$ Centro de Estudios Científicos, Valdivia, Chile \\ ${ }^{3}$ Universidad de Magallanes, Punta Arenas, Chile \\ Email: jorge.carrasco@meteochile.cl
}

Received May 21, 2013; revised June 18, 2013; accepted June 25, 2013

Copyright (C) 2013 Jorge F. Carrasco. This is an open access article distributed under the Creative Commons Attribution License, which permits unrestricted use, distribution, and reproduction in any medium, provided the original work is properly cited.

\begin{abstract}
An analysis of the minimum air temperature behavior was carried out for the southern tip of South America and the western side of the Antarctica Peninsula. Punta Arenas shows an overall annual warming of $0.15^{\circ} \mathrm{C}$ per decade during the 1960-2010 period, although this occurred mainly in the summer and winter seasons. The trend of the air temperature in the western side of the Antarctic Peninsula shows an increase until around 2000, but the warming rate during the last 2001-2010 decade has been less than previous decades; in particular, meteorological stations in King George Island show slight cooling. The lineal annual warming per decade as shown by Bellingshausen, Verndsky/Faraday and Rothera stations are $0.26^{\circ} \mathrm{C} \pm 0.75^{\circ} \mathrm{C}, 0.55^{\circ} \mathrm{C} \pm 1.26^{\circ} \mathrm{C}$ and $0.69^{\circ} \mathrm{C} \pm 1.31^{\circ} \mathrm{C}$; for the respectively, $1969-2010,1951-2010$ and 1978-2010 periods. These rates of warming are slightly lower than those found for the same stations but for the 19692000, 1951-2000 and 1978-2000 periods.
\end{abstract}

Keywords: Air Temperature; Exponential Filter; Global Warming; Antarctic Peninsula

\section{Introduction}

During the last decades global warming has becoming an increasing issue around the world. The physical science basis behind the observed and predicted changes, as well as, the implication of the climate change has been a permanent preoccupation since the eighties. On one hand, the science community investigates and produces the assessment reports around every 6 years about the stateof-the-art of what is known about climate change [1-3]; and on the other, govern representatives meet every year (the United Nations Framework Convention on Climate Change) with the aim of stabilizing the greenhouse gas concentrations in the atmosphere to prevent dangerous and irreversible anthropogenic changes in the climate system. Overall, the continental air temperature has increased by $0.84^{\circ} \mathrm{C}-1.12^{\circ} \mathrm{C}$ over the period 1901-2010, with the rate of warming increasing during the last 2 - 3 decades [4], or $0.13^{\circ} \mathrm{C} \pm 0.13^{\circ} \mathrm{C}$ per decade according with Hansen et al. [5]. The West Antarctica region which includes the Antarctic Peninsula (AP, hereafter) and the Marie Byrd Land is the region where the increased air temperature is the highest registered on the planet during the last few decades [6-10], as a consequence of the an- thropogenic greenhouse increased. In contrast, the rest of the Antarctic continent does not show the same rate of warming but rather a slight cooling [11,12]. However, an analysis of the mid-tropospheric air (above the inversion layer) the whole Antarctica shows an increase in temperature [13].

Most of the Antarctic continent is located southern of $70^{\circ} \mathrm{S}$ surrounded by the southern oceans with average near-surface air temperatures below $0^{\circ} \mathrm{C}$ all year-round. The AP is a relative narrow mountain barrier that extends northward from Ellsworth Land for about $1300 \mathrm{~km}$ until near $63^{\circ} \mathrm{S}$, leaving to the north the Drake Passage, to the west the southern Pacific Ocean and to the east the southern Atlantic Ocean. The AP is a complex orographic feature with several ice shelves adjacent to its coast and several glaciers draining into the ice shelves or directly to the ocean.

The mean sea-level pressure [14] in the southern polar region indicates that the AP is within the surface circumpolar trough affected by the atmospheric cyclonic circulations yielding a prevailing north/northwesterly airflow in its western side, and a prevailing southerly wind in its eastern side. The steep mountains and the nearly permanent surface circulations result into two distinct climatic 
environments at each side of the Peninsula. The north/ northwesterly winds in the western side bring relatively warmer and moister air, defining a sub-polar climate. While, the southerly winds in the eastern coast bring cold air from the continent and define a polar continental climate. This climatic difference is also manifested by other parameters like cloudiness, relative humidity, and precipitation/accumulation which are higher over the western side [15].

As a consequence of the regional warming in the AP, ice shelves adjacent to the peninsula have collapsed and retreated during recent decades [16]. The ice shelves do not contribute directly to sea level rise; however, their disintegration can change the dynamic of glaciers that before the collapse drained onto solid ice shelves, and after they can directly drain to the ocean contributing to sea level rise [17]. Here is, therefore, the importance of monitoring and understanding the atmospheric changes in the AP.

The worldwide increase in the air temperature, with higher rate in the last 2 - 3 decades [5] has not been observed in the northern tip of the AP during the last 20012010 decade $[12,18,19]$; therefore, it remains to be investigated if this behavior is a signal of a natural mechanism overcoming the anthropogenic forcing, or a response to local environmental changes. Here, an analysis based on selected stations located in the western side of the AP is presented to evaluate the warming of the region (Figure 1) on decadal and long-term time scales. The air temperature series from Punta Arenas is included in the analysis to compare with the changes in the southern tip of South America.

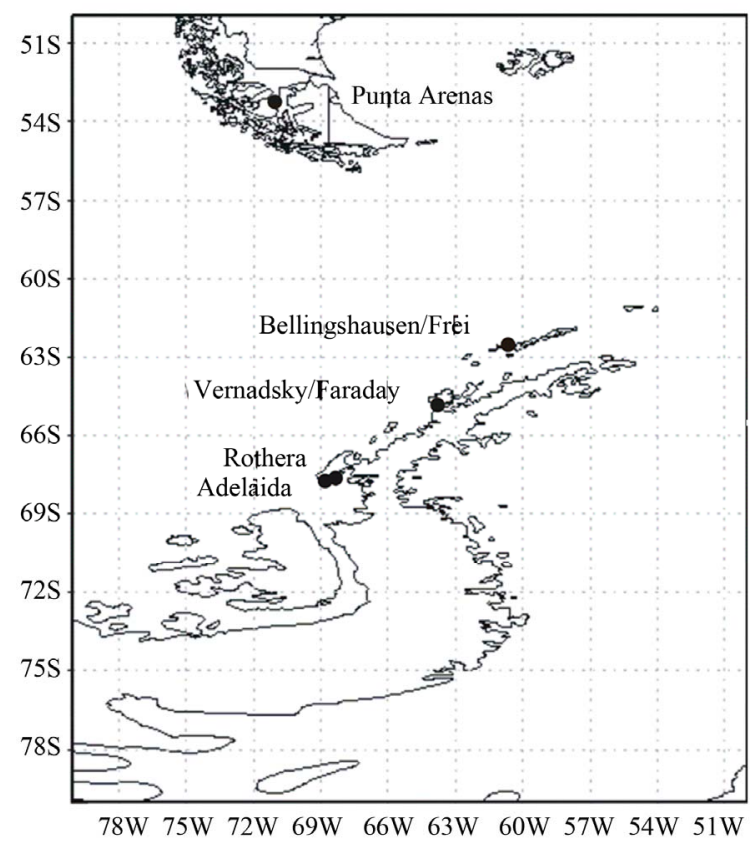

Figure 1. Location map with the geographical distribution of the meteorological stations.

\section{Methods}

Daily and monthly data of air temperature for Punta Arenas (53.0S, $70.9 \mathrm{~W}, 37 \mathrm{~m}$ asl), Bellingshausen/Frei (62.2S, $58.9 \mathrm{~W}, 10 \mathrm{~m}$ asl), Vernadsky/Faraday $(65.4 \mathrm{~S}, 64.4 \mathrm{~W}, 11$ $\mathrm{m}$ asl), Rothera (67.5S, $68.1 \mathrm{~W}, 32 \mathrm{~m}$ asl) and Adelaida (67.8S, $68.9 \mathrm{~W}, 26 \mathrm{~m}$ asl); were obtained from the Dirección Meteorológica de Chile and from the British Antarctic Survey. This last institute allows downloadding meteorological data from the scar_egoma google interface and the Met READER Project (www.antarctica.ac.uk/met/ READER/) $[8,20]$. The daily minimum air temperature recorded in Punta Arenas and Frei, and the daily air temperatures recorded at 12:00 UTC (Universal Time Coordinate) were used to calculate daily-decadal averages. Then the data were smoothed by applying an exponential filter [21] given by:

$$
\begin{gathered}
y_{t}=c x_{t}+(1-c) y_{t-1} \quad t=2,3, \quad n \\
z_{t}=c y_{t}+(1-c) z_{t+1} \quad t=(n-1),(n-2), \quad 1
\end{gathered}
$$

where Equations (1) and (2) are respectively the first forward and second backward smoothing. The first value $y_{t}$ is the average of the first 10 values of the series and $z_{t}$ corresponds to the final value of the first smoothing. The degree of smoothing $(c)$ can range from 1 (maximum, reproduced the original data) to 0 (it gives a straight line). Here, it was used $c=0.05$ for smoothing the decadal average annual cycle, this allows to filter out the high interdaily variability. For the time series analysis, $c=0.2$ was preferred in order to filter out the high inter-annual variability but to keeps the longer term behavior. Graphs in Figure 2 were constructed using the minimum or the 12 UTC air temperatures, while the trends in Table 1 were calculated using the monthly means.

\section{Results}

The air temperature analysis shows an overall warming of $0.73^{\circ} \mathrm{C}$ during $1960-2010$ period, in the southern tip of South America as revealed by Punta Arenas station. However, analyzing the time series for the periods before and after the 1976/1977 climate shift [22], it can be seen that for the 1961-1976 period the air temperature behavior does not reveal a trend while the 1978-1995 period shows a cooling. Only after the mid-90s the time series reveals a positive trend. The analysis indicates that warming observed in Punta Arenas in the last 5 decades is mostly associated with the shift of the atmospheric-ocean system over the North Pacific Ocean, in other words, by the Pacific Decadal Oscillation (PDO) [22], also called the Pacific Decadal Variability (PDV) [21].

Decadal average of the daily air temperatures and the annual long-term are shown in Figure 2. All stations show an overall increase in air temperature, however, the 

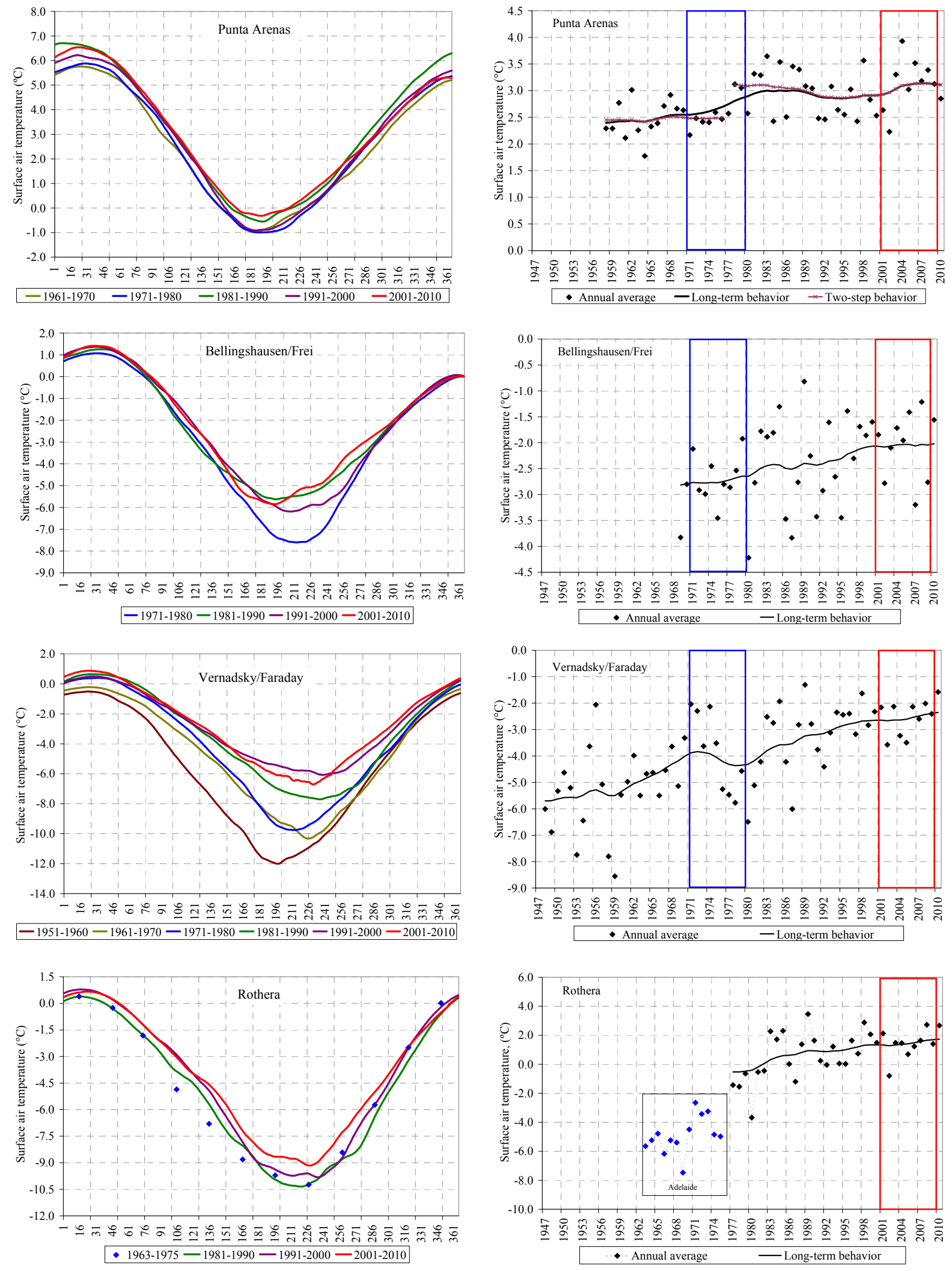

Figure 2. Decadal average of the annual cycle (left side) and annual average long-term (right side) behavior of the near-surface air temperature, after applying the exponential filter. Blue rhombuses in Rothera graph are monthly and annually average from the nearby Adelaide station. 
Table 1. Annual and seasonal linear trends (per decade) for stations located in the Antarctic Peninsula updated from Turner et al. [8]. Italics (bold) numbers are significant at $10 \%(5 \%)$, while those italic/bold are significant at $1 \%$. Added is Frei station [20]. ${ }^{\#}$ Values are from Bromwich et al. [10].

\begin{tabular}{|c|c|c|c|c|c|c|}
\hline Station & Annual & Spring & Summer & Autumn & Winter & Period \\
\hline Frei & $\begin{array}{l}0.21 \pm 0.35 \\
0.11 \pm 0.71\end{array}$ & $\begin{array}{c}0.22 \pm 0.46 \\
-0.06 \pm 0.87\end{array}$ & $\begin{array}{c}0.05 \pm 0.09 \\
-0.06 \pm 0.43\end{array}$ & $\begin{array}{l}\mathbf{0 . 3 9} \pm \mathbf{0 . 3 3} \\
0.17 \pm 0.96\end{array}$ & $\begin{array}{l}0.62 \pm 2.40 \\
0.39 \pm 1.86\end{array}$ & $\begin{array}{l}1970-2000 \\
1970-2010\end{array}$ \\
\hline Rothera & $\begin{array}{l}1.01 \pm 1.42 \\
0.69 \pm 1.31\end{array}$ & $\begin{array}{l}1.06 \pm 1.53 \\
\mathbf{0 . 7 6} \pm \mathbf{1 . 5 1}\end{array}$ & $\begin{array}{l}0.36 \pm 0.57 \\
0.18 \pm 0.56\end{array}$ & $\begin{array}{l}1.37 \pm 1.46 \\
0.67 \pm 1.32\end{array}$ & $\begin{array}{l}1.73 \pm 2.79 \\
1.09 \pm 2.87\end{array}$ & $\begin{array}{l}1978-2000 \\
1978-2010\end{array}$ \\
\hline Vernadsky/Faraday & $\begin{array}{l}0.56 \pm 0.43 \\
0.55 \pm 1.26\end{array}$ & $\begin{array}{l}0.25 \pm 0.44 \\
\mathbf{0 . 3 9} \pm \mathbf{1 . 4 3}\end{array}$ & $\begin{array}{l}0.24 \pm 0.17 \\
0.23 \pm 0.63\end{array}$ & $\begin{array}{l}0.63 \pm 0.60 \\
0.52 \pm 1.62\end{array}$ & $\begin{array}{l}1.09 \pm 0.88 \\
1.06 \pm 2.79\end{array}$ & $\begin{array}{l}1951-2000 \\
1951-2010\end{array}$ \\
\hline Bellingshausen & $\begin{array}{l}\mathbf{0 . 3 5} \pm \mathbf{0 . 4 6} \\
0.26 \pm 0.75\end{array}$ & $\begin{array}{c}-0.10 \pm 0.47 \\
0.10 \pm 0.91\end{array}$ & $\begin{array}{l}\mathbf{0 . 3 0} \pm \mathbf{0 . 2 0} \\
0.13 \pm 0.45\end{array}$ & $\begin{array}{l}\mathbf{0 . 5 1} \pm \mathbf{1 . 0 5} \\
0.33 \pm 1.04\end{array}$ & $\begin{array}{l}0.58 \pm 0.97 \\
0.48 \pm 1.89\end{array}$ & $\begin{array}{l}1969-2000 \\
1969-2010\end{array}$ \\
\hline Esperanza & $\begin{array}{l}0.41 \pm 0.42 \\
\mathbf{0 . 3 3} \pm \mathbf{1 . 0 8}\end{array}$ & $\begin{array}{c}-0.07 \pm 0.57 \\
0.14 \pm 1.52\end{array}$ & $\begin{array}{c}-\mathbf{0 . 0 7} \pm \mathbf{0 . 5 7} \\
\mathbf{0 . 1 4} \pm \mathbf{1 . 5 2}\end{array}$ & $\begin{array}{l}\mathbf{0 . 4 3} \pm \mathbf{0 . 3 4} \\
0.37 \pm 0.80\end{array}$ & $\begin{array}{l}0.51 \pm 0.82 \\
0.32 \pm 2.20\end{array}$ & $\begin{array}{l}1961-2000 \\
1961-2010\end{array}$ \\
\hline Marambio & $\begin{array}{c}<90 \% \\
\mathbf{0 . 4 5} \pm \mathbf{1 . 1 7}\end{array}$ & $\begin{array}{c}-0.80 \pm 10.5 \\
0.34 \pm 1.87\end{array}$ & $\begin{array}{c}<90 \% \\
\mathbf{0 . 5 1} \pm \mathbf{0 . 8 7}\end{array}$ & $\begin{array}{c}<90 \% \\
0.62 \pm 2.43\end{array}$ & $\begin{array}{l}0.81 \pm 1.53 \\
0.40 \pm 2.72\end{array}$ & $\begin{array}{l}1971-2000 \\
1971-2010\end{array}$ \\
\hline Central West Antarctica & $0.47 \pm 0.23$ & $0.82 \pm 0.40$ & $0.30 \pm 0.27$ & - & $0.54 \pm 0.51$ & $1958-2010$ \\
\hline
\end{tabular}

Antarctic ones reveal that the significant warming took place in winter months and before the 1991-2000 decade. In fact, the annual long-term behavior reveals no significant trend during the 2001-2010 period as suggested by Setzer et al. $[18,19]$. This also concurs with the results of Bromwich et al. [10] who found a substantial linear increase in annual temperature of $2.4^{\circ} \mathrm{C} \pm 1.2^{\circ} \mathrm{C}$ for the Central West Antarctica during the 1958-2010 period, but no positive trend for the last decade can be inferred from their Figure 2(a)) [10]. No relation between the behavior of the surface air temperature for the Antarctic stations and the PDO was found.

Table 1 shows a partial update of the linear regression of Table 1 from Turner et al. [8] for the stations located in the AP. Included are the trends for Frei station and the decadal trends found by Bromwich et al. [10]. Winter is the season with larger positive trends, except for Central West Antarctica region which experience the larger warming in spring season [10]. Trends obtained for periods ending in 2000 [8] are lower than those extended for the periods ending in 2010 [20]. This is because the air temperature does not show the previous rate of warming for the 2001-2010 decade (Figure 2).

\section{Discussion}

The southern tip of South America shows an overall warming but the significant increase of the air temperature concurs with the 1976/1977 climate shift. This relation is not found for Antarctic stations. The AP is one of the regions on Earth where annual air surface temperatures have experienced substantial warming at higher rate than global average [6-10]. However, decadal behavior of the air surface temperature reveals that this warming occurred before the last decade (2001-2010), at least in the northern tip of the AP. The warming has been related with the strengthening of the Antarctic Annular Oscillation (AAO) [23-25], i.e., a positive AAO trend, resulting in a southward displacement of the westerlies, which allows more relatively warm air passing over the AP. However, the summer warming in the Marie Byrd Land is not supported by the AAO as indicated by Bromwich et al. [10].

Results from this analysis show the same overall upward trend of the surface air temperature in the western side of the AP from previous works, but one intriguing result is that the air temperature reveals insignificant changes during the last decade in the northern tip of the AP as previously suggested by Setzer et al. [18,19]. In fact, Vernadsky/Faraday and Bellingshausen stations show a cooling in some spring-summer and winter months, respectively. The lineal annual warming per decade as shown by Bellingshausen, Verndsky/Faraday and Rothera stations are $0.26^{\circ} \mathrm{C} \pm 0.75^{\circ} \mathrm{C}, 0.55^{\circ} \mathrm{C} \pm 1.26^{\circ} \mathrm{C}$ and $0.69^{\circ} \mathrm{C}$ $\pm 1.31^{\circ} \mathrm{C}$; for the respectively, $1969-2010,1951-2010$ and 1978-2010 periods. These rates of warming are slightly lower than those found for the same stations but for the 1969-2000, 1951-2000 and 1978-2000 periods.

Figure 3 shows the long-term behavior of the global air temperature anomaly obtained from Climatic Research Unit (CRU) time series datasets of the University of East Anglia [26], along with those obtained for the Antarctic stations (upper part). Vernadsky/Faraday and Rothera stations show larger air temperature increases than the global average, but the annual trend is nearly flat during the last decade (2001-2010) at Bellingshausen/ 


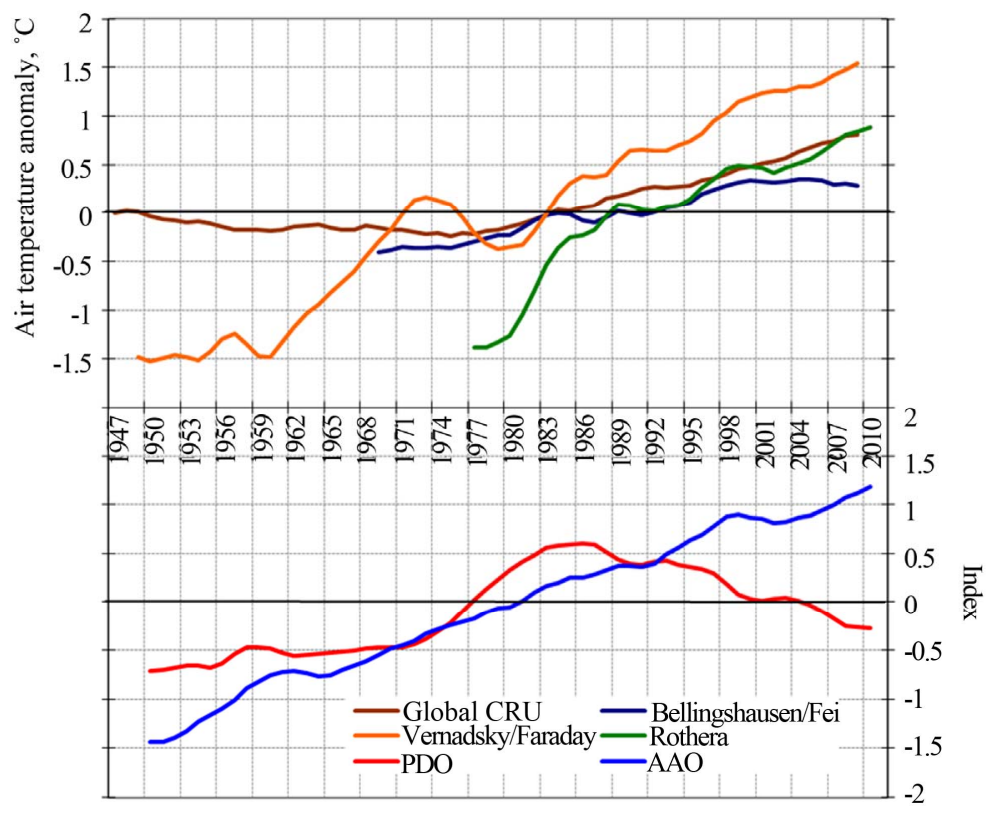

Figure 3. Long-term behavior using annual anomalies of the global air temperature and those obtained for Bellingshausen/ Frei, Vernadsky/Faraday and Rothera stations, after applying the exponential filter.

Frei station. On the other hand, the southernmost stations, Verndsky/Faraday and Rothera, show a continuing positive trend for the last decade. Figure 3 also includes the long-term behavior of the PDO and AAO as revealed by their respective indexes, after applying the exponential smoothing to filter out the inter-annual variability. A positive PDO is associated with a high pressure anomaly region centered to the west of the AP [27], and therefore, favors the relative cold air advection toward the western side of the AP. The fact that the PDO shows a positive (negative) trend until (after) mid 80s might suggest that cold air advection over the western side of the AP was becoming weaker (stronger) or less (more) frequent. However, the correlations between the PDO and the annual air temperature at each station are low and not statistically significant (Table 2), implying that the PDO does not play a significant role as mechanism supporting the observed warming (or eventual cooling). While on the other hand, positive AAO values indicate a predominant negative pressure anomalies in the Antarctic continent, surrounded by positives anomalies around $40^{\circ} \mathrm{S}-60^{\circ} \mathrm{S}$ [24,25]. This results in a southward displacement and strengthening of the westerly airflow favoring the warm air advection on the AP. The correlations between AAO index and the annual surface air temperature at each station are above 0.65 (Table 2) and statistically significant at $\alpha=0.05$. Therefore, the overall behavior of the AAO supports the warming of the AP [12].

In summary, the lineal trend that includes the surface air temperature data until 2010 in the western side of the AP, mainly in its northern tip; shows warming rate less
Table 2. Matrix of correlation (Pearson) among the stations and the AAO and PDO indexes, obtained from the original data without filtering. Bold numbers are statistically significant at $\alpha=0.05(B=$ Bellinghausen, $V / F=$ Vernadsky $/$ Faraday, $\mathbf{R}=$ Rothera).

\begin{tabular}{cccc}
\hline & $\mathrm{B}$ & $\mathrm{V} / \mathrm{F}$ & $\mathrm{R}$ \\
\hline AAO & $\mathbf{0 . 6 8}$ & $\mathbf{0 . 6 6}$ & $\mathbf{0 . 7 8}$ \\
PDO & -0.31 & -0.33 & -0.30 \\
Vernadsky/Faraday & $\mathbf{0 . 5 7}$ & - & $\mathbf{0 . 7 9}$ \\
Bellingshausen & - & - & $\mathbf{0 . 7 6}$ \\
\hline
\end{tabular}

than those obtained when the series ended in 2000 [8]. This is a result of less warming rate during 2001-2010 period, or even a slight cooling in the northern tip of the AP. However, this different behavior, observed in the northern tip of the AP during the last decade, dose not necessary support the assertion that the trend or the rate of global warming is less after mid 90s [28], so that the explanation can be found in the local environmental changes and interaction among atmosphere-ocean-sea ice, rather than large scale forcing like stratospheric water vapor concentrations even though this can be an important driver for a global climate change [28].

\section{Acknowledgements}

This work was supported by the Project Bicentennial Science and Technology Programme of CONICYT (Scientific and Technological National Commission of Chile), Proyecto Anillo Bicentenario ARTG02-2006. 


\section{REFERENCES}

[1] IPCC, "Climate Change 2007: The Physical Science Basis. Contribution of Working Group I to the Fourth Assessment Report of the Intergovernmental Panel on Climate Change," In: S. Solomon, D. Qin, M. Manning, Z. Chen, M. Marquis, K. B. Averyt, M. Tignor and H. L. Miller, Eds., Cambridge University Press, Cambridge and New York, 2007.

[2] IPCC, "Climate Change 2007: Impacts, Adaptation and Vulnerability. Contribution of Working Group II to the Fourth Assessment Report of the Intergovernmental Panel on Climate Change," In: M. L. Parry, O. F. Canziani, J. P. Palutikof, P. J. van der Linden and C. E. Hanson, Eds., Cambridge University Press, Cambridge, 2007.

[3] IPCC, “Climate Change 2007: Mitigation, Contribution of Working Group III to the Fourth Assessment Report of the Intergovernmental Panel on Climate Change,” In: B. Metz, O. R. Davidson, P. R. Bosch, R. Dave, L. A. Meyer, Eds., Cambridge University Press, Cambridge and New York, 2007.

[4] P. D. Jones, D. H. Lister, T. J. Osbom, C. Harphan, M. Salmon and C. P. Morice, "Hemispheric and Large-Scale Land-Surface Air Temperature Variations: An Extensive Revision and Update to 2010," Journal of Geophysical Research, Vol. 117, 2012, Article ID: D05127.

[5] J. Hansen, R. Ruedy, M. Sato and K. Lo, "Global Surface Temperature Change," Review of Geophysics, Vol. 48, No. 4, 2010, Article ID: RG4004. doi:10.1029/2010RG000345

[6] D. G. Vaughan, G. J. Marshall, W. M. Connolley, C. Parkinson, N. R. Mulvaney, D. A. Hodgson, J. C. King, C. J. Pudsey and J. Turner, "Recent Rapid Regional Climate Warming on the Antarctic Peninsula," Climatic Change, Vol. 60, No. 3, 2003, pp. 243-274. doi:10.1023/A:1026021217991

[7] Q. Din, D. S. Batisti and M. Kuttel, "Winter Warming in West Antarctica Caused by Central Tropical Pacific Warming," Nature Geoscience, Vol. 4, No. 6, 2011, pp. 398403. doi:10.1038/ngeo1129

[8] J. Turner, J. C. Comiso, G. J. Marshall, T. A. LachanCope, M. A. Carleton, P. D. Jones, V. Lagun, P. A. Reid and S. Iagovkina, "Antarctic Climate Change during the Last 50 Years," International Journal of Climatology, Vol. 25, No. 8, 2005, pp. 279-294. doi:10.1002/joc.1130

[9] Q. Din, D. S. Batisti and M. Kuttel, "Winter Warming in West Antarctica Caused by Central Tropical Pacific Warming," Nature Geoscience, Vol. 4, No. 6, 2011, pp. 398403. doi:10.1038/ngeo1129

[10] D. H. Bromwich, J. P. Nicolas, A. Monaghan, M. A. Lazzara. L. M. Keller, G. A. Weidner and A. B. Wilson, "Central West Antarctica among the Most Rapidly Warming Regions on Earth," Nature Geoscience, Vol. 6, No. 2, 2012, pp. 139-145.

[11] P. T. Doran, J. C. Priscu, W. B. Lyons, J. E. Walsh, A. G. Fountain, D. M. McKnight, D. L. Moorhead, R. A. Virginia, D. H. Wall, G. D. Clow, C. H. Fritsen, C. P. McKay and A. N. Parsons, "Antarctic Climate Cooling and Terrestrial Ecosystem Response,” Nature, Vol. 415, No.
6871, 2002, pp. 517-520. doi:10.1038/nature710

[12] A. J. Monaghan, D. H. Bromwich, W. Chapman and J. C. Comiso, "Recent Variability and Trends of Antarctic NearSurface Temperature," Journal of Geophysical Research, Vol. 113, No. 457, 2008, Article ID: D04105. doi:10.1029/2007JD009094

[13] J. Turner, T. A. Lachan-Cope, S. Colwell, G. J. Marshall, and W. M. Connolley, "Significant Warming of the Antarctic Winter Troposphere," Science, Vol. 311, No. 5769, 2006, pp. 1914-1917. doi:10.1126/science. 1121652

[14] W. Schwerdtfeger, "Weather and Climate of the Antarctic," Elsevier, New York, 1984.

[15] D. G. Vaughan, J. L. Bamber, M. Giovinetto, J. Russell and A. P. R. Cooper, "Reassessment of Net Surface Mass Balance in Antarctica," Journal of Climate, Vol. 12, No. 4, 1999, pp. 933-946. doi:10.1175/1520-0442(1999)012<0933:RONSMB $>2.0$. $\mathrm{CO} ; 2$

[16] A. J. Cook and D. G. Vaughan, "Overview of Areal Changes of the Ice Shelves on the Antarctic Peninsula over the Past 50 Years," The Cryosphere, Vol. 4, No. 1, 2010, pp. 77-98. doi:10.5194/tc-4-77-2010

[17] E. Rignot, G. Casassa, P. Gogineni, W. Krabill, A. Rivera and R. Thomas, "Accelerated Ice Discharge from the Antarctic Peninsula Following the Collapse of Larsen B Ice Shelf," Geophysical Research Letters, Vol. 31, No. 18, 2004, Article ID: L18401. doi:10.1029/2004GL020697

[18] A. W. Setzer, F. E. Aquino and R. M. O. Romao, "Climate Tendencies in the South Shetlands: Was 1998 a Climate Divider?" Antarctic Peninsula Climate Variability: Observed, Models and Plans for IPY Research, University of Colorado, Boulder, 14-16 May 2006.

[19] A. W. Setzer and R. M. O. Romao, "Recent Cooling in the North of the Antarctic Peninsula," 4th SCAR Open Science Conference, Buenos Aires, 2010.

[20] J. F. Carrasco, "Red de Estaciones de Observación Atmosférica en la Antártica, una Colaboración Internacional Para la Investigación del Cambio Climático," Anales Instituto Patagonia, Vol. 40, No. 1, 2012, pp. 57-63. doi:10.4067/S0718-686X2012000100006

[21] B. Rosenbluth, H. A. Fuenzalida and P. Aceituno, "Recent Temperatures Variations in Southern South America," International Journal of Climatology, Vol. 17, 1997, pp. 67-85. doi:10.1002/(SICI)1097-0088(199701)17:1<67::AID-JO C120>3.0.CO;2-G

[22] B. S. Giese, S. C. Urizar and N. S. Fuckar, "Southern Hemisphere Origins of the 1976 Climate Shift," Geophysical Research Letter, Vol. 29, No. 2, 2002, p. 1014. doi:10.1029/2001GL013268

[23] C. Wang, C. Deser, J.-Y. Yu, P. DiNezio and A. Clement, "El Niño Southern Oscillation (ENSO): A Review," In: P. Glymn, D. Manzello and I. Enochs, Eds, Coral Reefs of the Eastern Pacific, Spring Science Publisher, 2012.

[24] D. W. J. Thompson and S. Solomon, "Interpretation of recent Southern Hemisphere Climate Change," Science, Vol. 296, No. 5569, 2002, pp. 895-899. doi: $10.1126 /$ science. 1069270 
[25] D. W. J. Thompson and J. M. Wallace, "Annular Mode in the Extratropical Circulation. Part I: Monthly-to-Month Variability," Journal of Climate, Vol. 13, 2000, pp. 10001006.

doi:10.1175/1520-0442(2000)013<1000:AMITEC $>2.0 . C$ $\underline{\mathrm{O} ; 2}$

[26] I. Harris, P. D. Jones, J. T. Osborn and D. H. Lister, "Update High-Resolution Grids of Monthly Climatic Observations," International Journal of Climatology, 2012, in Press. doi:10.1002/joc.3711

[27] R. D. Garreaud and D. S. Battisti, "Interannual (ENSO) and Interdecadal (ENSO-Like) Variability in the Southern Hemisphere Tropospheric Circulation," Journal of Climate, Vol. 12, No. 7, 1999, pp. 2113-2123. doi: 10.1175/1520-0442(1999)012<2113:IEAIEL $>2.0 . C O$ ;2

[28] S. Salomon, K. H. Rosenlof, R. W. Portmann, J. S. Daniel, S. M. Davis, T. J. Sanford and G.-K. Plattner, "Contributions of Stratospheric Water Vapor to Decadal Changes in the Rate of Global Warming," Science, Vol. 327, No. 5970, 2010, pp. 1219-1223. doi:10.1126/science. 1182488 